\title{
МАТВІЙЧУК А. В.,
} кандидат юридичних наук, доцент кафедри правосуддя юридичного факультету (Інститут управління, технологій та права імені гетьмана Петра Конашевича-Сагайдачного Державного університету інфраструктури та технологій)

УДК 342.631 (477)

DOI https://doi.org/10.32842/2078-3736-2019-3-2-13

\section{АДМІНІСТРАТИВНО-ПРАВОВЕ РЕГУЛЮВАННЯ УЧАСТІ ЧЛЕНІВ ТЕРИТОРІАЛЬНИХ ГРОМАД У МІСЦЕВОМУ САМОВРЯДУВАННІ}

У статті проаналізовано особливості адміністративно-правового регулювання механізму застосування таких інструментів громадського впливу на діяльність місцевих органів влади як громадський моніторинг та громадські слухання та запропоновано способи вдосконалення відносин соціально-територіального самоуправління.

Ключові слова: адміністративно-правове регулювання, громадський моніторинг, громадські слухання, місиева виконавча влада, органи місиевого самоврядування, територіальна громада.

В статье проанализированы особенности административно-правового регулирования механизма применения таких инструментов общественного влияния на деятельность местных органов власти как общественный мониторинг и общественные слушания и предложены способы совершенствования отношений социально-территориального самоуправления.

Ключевые слова: административно-правовое регулирование, общественный мониторинг, общественные слушания, местная исполнительная власть, органы местного самоуправления, территориальная община.

The article analyzes the peculiarities of administrative and legal regulation of the use of such instruments of public influence on the activities of local authorities as public monitoring and public hearings and proposes ways to improve the relations of social and territorial self-government.

Key words: administrative-legal regulation, public monitoring, public hearings, local executive power, bodies of local self-government, territorial community.

Вступ. Розвиток системи місцевого самоврядування є особливо важливим фактором становлення громадянського суспільства у нашій державі. 3 моменту проголошення самостійності в Україні розпочалося утвердження в ііі суспільно-політичному житті процесів реального забезпечення засад демократичної та правової держави, визначених у Конституції України [1].

Впровадження нових законодавчих та підзаконних нормативно-правових актів на початковому етапі закріплення власної незалежності в Україні пов'язане 3 необхідністю вироблення власної стратегії державотворення та механізмів іiї оптимальної реалізації в усіх

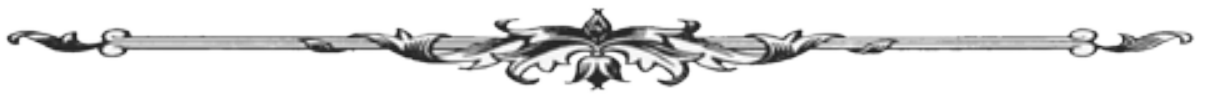


секторах суспільно-політичних відносин. Зокрема, Закон України «Про місцеве самоврядування в Україні» визначив одним із основних напрямів державної політики на майбутні періоди створення належних передумов для розвитку місцевого самоврядування в Україні, а одним із важливих завдань - розвиток ініціативи населення у вирішенні питань місцевого значення [2].

Дослідження науково-теоретичних позицій фахівців щодо правового регулювання відносин місцевого самоврядування дає підстави зробити висновок про те, що вітчизняні науковці досягли певних результатів в осмисленні механізмів удосконалення діяльності різних інститутів громадського самоуправління. Однак, результати дослідження гласності та відкритості процесу нормативно-правової діяльності органів місцевого самоврядування у межах науки адміністративного, конституційного, муніципального права, зокрема питань громадського контролю (громадського моніторингу та громадського обговорення), нормотворення та правозастосування, наявні у наукових доробках окремих вітчизняних і зарубіжних учених В.Б. Авер'янова, В.М. Алексєєва, О.В. Батанова, М.О. Баймуратова, В.Ф. Бойко, Л.М. Воротіна, І.О. Гуменюк, О.О. Кравченко, П.М. Любченко, О.І. Музи, Н.М. Нижник, В.Ф. Погорілко, Ю.О. Тихомирова, В.М. Скрипничук та інших.

Оскільки місцеве самоврядування можна визначити не лише як специфічний прояв влади, що іiі здійснює у певних організаційних формах населення, що входить до територіальної громади [3, с. 273]; а і як прояв громадської активності, автор дослідження вирішив звернутися до дослідження адміністративно-правових засад забезпечення участі громадян у місцевому самоврядуванні з метою розширення обсягу досліджень про різні аспекти адміністративного провадження як процесу здійснення регуляторної діяльності.

Постановка завдання. Метою статті є розгляд особливостей реалізації таких інструментів громадського впливу на нормотворчу правозастосовну діяльність органів місцевої виконавчої влади та органів місцевого самоврядування як громадський моніторинг та громадські слухання у системі адміністративно-правового регулювання відносин соціально-територіального самоуправління.

Результати дослідження. На сучасному етапі розвитку України як незалежної держави українське суспільство прагне до відродження історичної спадщини та національних традицій, проголошуючи одним із першочергових завдань створення самодостатніх територіальних громад як одного з основних важелів розвитку місцевого самоврядування у демократичній країні. Практична реалізація поставлених завдань залежить від проведення широкомасштабної реформи державного управління та тісно пов'язана із необхідністю кардинальних змін у системі правового забезпечення місцевого самоврядування та адміністративно-територіальної організації влади.

Характеризуючи вищезазначені суспільні відносини, Н.Р. Нижник зазначає, що механізми адміністративно-правового регулювання у системі місцевого самоврядування побудовані таким чином, що управління здійснюється не безпосередньо громадою, а через місцевий апарат управління, який, у порівнянні з територіальною громадою, може відстоювати інші інтереси. Однією з причин такого стану справ є те, що громадянське суспільство не має належної можливості брати участь у вирішенні загальнодержавних та місцевих справ [4, с. 56].

Повністю погоджуючись із позицією науковця, варто зауважити, що громадськість, маючи чіткі законодавчі повноваження, має здійснювати постійний контроль за прийняттям відповідних рішень органами місцевого самоврядування, які стосуються питань життєзабезпечення територіальних громад та їх спільної власності, через моніторинг проектів нормативно-правових актів з метою недопущення прийняття тих положень, які можуть спричинити негативні соціальні, екологічні та демографічні наслідки. Доцільність такого виду громадського аналізу контролю за реалізацією владних повноважень місцевими органами пояснюється і тим, що у переважній більшості випадків йдеться не про організаційні питання відповідних рад та їх виконавчих органів, що стосуються повсякденних проблем, вирішення яких не завжди співпадає є думкою жителів окремих населених пунктів чи всієї територіальної громади.

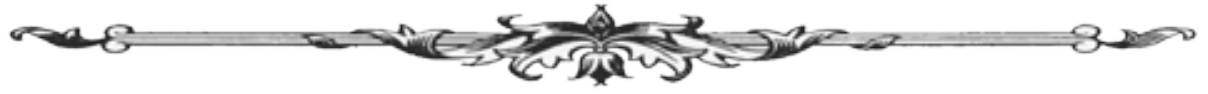


Необхідність підвищення ефективності та дієвості норм законодавства, що регулює повноваження владних органів місцевого самоврядування та зміцнення законності у цій сфері, обумовлює завдання для представників вітчизняної науки щодо розробки та вдосконалення правового механізму «громадського моніторингу, нового явища у теорії та практиці» [5, с. 12]. За твердженням науковця Ю. Тихомирова, «мета моніторингу - забезпечення систематичного спостереження, аналізу та оцінки і коригування діяльності органів публічної влади» [5, с. 13].

Досліджуючи питання адміністративно-правових засад громадського моніторингу за діяльністю органів державної влади та органів місцевого самоврядування, ще у першому десятилітті незалежності України О.В. Батанов зазначав, що з приводу цього питання у ряді зарубіжних країн вироблена чітка стратегія та приділяється достатня увага науковців удосконаленню системи правового регулювання різних видів громадського контролю за діяльністю органів державної виконавчої влади, пропонував запровадження окремих зразків зарубіжного досвіду у систему національного правового регулювання цього виду суспільно-політичних відносин [6, с. 112].

Відповідно до Закону України «Про місцеве самоврядування в Україні», який визначає систему та гарантії місцевого самоврядування, засади організації, діяльності, правового статусу і відповідальності органів та посадових осіб місцевого самоврядування [2], а також ряду інших нормативно-правових актів, що регулюють організаційні, економічні та правові засади організації місцевої влади, члени територіальних громад можуть застосовувати такі форми контролю за діяльністю органів місцевого самоврядування: 1) рішення загальних зборів громадян; 2) місцеві ініціативи, внесені на розгляд ради у встановленому порядку; 3) пропозиції, які вносяться за результатами громадських слухань і підлягають обов'язковому розгляду органами місцевого самоврядування; 4) місцеві референдуми.

Перелічені механізми втручання членів громади у нормотворчу діяльність органів місцевого самоврядування на практиці майже не використовуються через відсутність дієвого адміністративно-правового механізму оперативного реагування, який повинен сприяти захисту територіальних громад від протиправних рішень чи небажаних наслідків, що можуть виникнути внаслідок прийняття місцевими органами виконавчої влади та органами місцевого самоврядування нормативно-правових актів.

Досліджуючи проблематику адміністративно-правових засад регуляторної діяльності в Україні, варто зазначити, що основні проблеми у застосуванні актів регуляторного законодавства на регіональному рівні здебільшого виникають з таких причин: 1) суперечність окремих положень деяких законодавчих актів положенням Конституції України та іншим законам України; 2) наявність прогалин у законодавстві, що породжує протистояння між структурами, які здійснюють управління на місцевому рівні; 3) відсутність моніторингу проектів нормативно-правових актів на регіональному рівні тощо.

Перелік перешкод для ефективного громадського контролю за діяльністю місцевих органів влади доповнює В.В. Мушенок, який зазначає, що при низькому рівні доходів місцевих бюджетів органи місцевої влади без належного обгрунтування здебільшого зловживають своїми повноваженнями щодо здійснення несвоєчасних та не в повному обсязі бюджетних виплат, підвищують ставки податків і зборів тощо [7, с. 96]. Усе це породжує недовіру громадян до законних дій органів місцевого самоврядування.

Виходячи з вищезазначеного, пропоную для обговорення науковців, практиків та експертів власне бачення нормативних передумов, наслідком яких $є$ відсутність належного розвитку системи громадського моніторингу на місцевому та регіональному рівнях та визначення прогалин у нормативно-правових актах, що перешкоджають здійсненню визначених Конституцією України повноважень органами місцевого самоврядування у процесі співпраці з громадами та громадськими організаціями.

Відповідно до норм Конституції України у Законі України «Про місцеве самоврядування в Україні» передбачено, що місцеве самоврядування в Україні - це гарантоване державою право та реальна здатність територіальної громади - жителів села чи добровільного

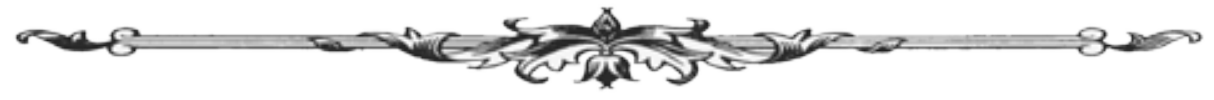


об’єднання у сільську громаду жителів кількох сіл, селища, міста самостійно або під відповідальність органів та посадових осіб місцевого самоврядування вирішувати питання місцевого значення в межах Конституції і законів України. Місцеве самоврядування здійснюється територіальними громадами сіл, селищ, міст як безпосередньо, так і через сільські, селищні, міські ради та їх виконавчі органи, а також через районні та обласні ради, які представляють спільні інтереси територіальних громад сіл, селищ, міст [2].

Однією 3 причин відсутності належним чином організованої роботи громадських організацій по моніторингу за прийняттям проектів регуляторних актів органами місцевого самоврядування є відсутність належної законодавчої основи у базовому Законі України «Про місцеве самоврядування в Україні» та в інших нормативно-правових актах.

Повністю поділяючи позицію В.В. Мушенка про те, що закони як основоположні нормативні акти у вітчизняній правовій системі є відносно стабільними та приймаються на тривалий час, а можливість швидко реагувати на зміни у суспільно-економічному житті та ефективно забезпечувати правове регулювання конкретних проблемних питань різних сфер держава здійснює за допомогою інших правових інструментів, якими є постанови Кабінету Міністрів України [7, с. 36]; прийняття Кабінетом Міністрів України постанови про затвердження Державної програми громадського контролю щодо ефективності застосування нормативно-правових актів органами місцевої виконавчої влади та місцевого самоврядування.

Така програма повинна містити чіткий правовий механізм та організаційну структуру, повноваження громадських організацій щодо проведення моніторингу, а також визначення методів взаємодії з відповідними державними та недержавними установами та організаціями. За інших обставин неможливо сподіватися на позитивний результат громадського моніторингу ефективності застосування нормативно-правових актів місцевого значення у разі його проведення без взаємозв'язку із вказаними структурами, що відповідно до законодавства наділені повноваженнями приймати такі нормативно-правові акти.

Важливим чинником ефективності вирішення визначених питань повинна стати робота місцевих громадських організацій, які співпрацюватимуть із відповідними підрозділами обласних та районних рад, що дозволить отримувати об'єктивну інформацію про прогалини у чинному законодавстві стосовно здійснення місцевого самоврядування в Україні та знайти спільні підходи до його вдосконалення. У цьому процесі не потрібно обмежувати коло учасників моніторингу ефективності нормотворчої та правозастосовної діяльності органів місцевої влади. Необхідно брати до уваги та розглядати слушні пропозиції від спеціалізованих громадських організацій (асоціацій, спілок), громадських рад тощо.

Вищезазначена програма також повинна містити чіткі механізми залучення представників громадськості, науковців, досвідчених експертів та інших професіоналів, які мають достатній практичний досвід, оскільки проведення громадського моніторингу нормотворчої діяльності місцевих органів влади необхідне за багатьма напрямами та потребуватиме використання норм законодавства різної галузевої спрямованості.

Авторська позиція є солідарною з позицією В. Бабаєва, який зазначає, що залучивши широке коло учасників процесу громадського контролю за діяльністю місцевих органів, можна сподіватися на більш позитивний результат, що моніторинг буде дієвим, пропонуватимуться не тільки пропозиції щодо змін та доповнень до чинного законодавства, а й новації, які є важливими для практичної реалізації визначених законодавством повноважень [9, с. 25].

Ефективне проведення громадського моніторингу діяльності органів місцевого самоврядування залежить від: 1) належного рівня нормативно-правового закріплення функцій та повноважень громадських організацій; 2) наукового, організаційного та кадрового забезпечення громадських організацій; 3) належної матеріальної бази для роботи громадських (неприбуткових) організацій; 4) налагодження ефективної співпраці з об'єктами громадського моніторингу та іншими установами і організаціями тощо.

У контексті дослідження системи адміністративно-правового регулювання участі громадян у місцевому самоврядуванні поряд із громадським моніторингом здійснено ана-

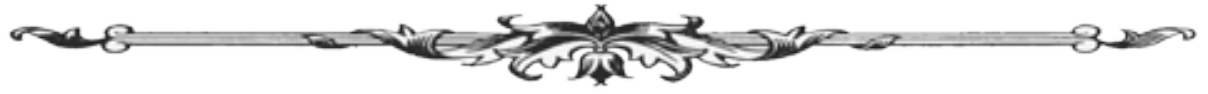


ліз іншого правового інструменту громадського контролю за діяльністю органів виконавчої влади - громадських слухань.

Окремі правові механізми контролю за вирішення питань місцевого значення закріплені у Законі України «Про місцеве самоврядування в Україні». Цей закон передбачає, що вирішення питань місцевого значення може відбуватися шляхом проведення місцевих референдумів, зібрання загальних зборів усіх чи частини жителів села, селища, міста [2]. 3i змісту закону можна зробити висновок про те, що громадські слухання можуть проводитись із питань, що мають важливе побутове, соціальне чи економічне значення для жителів того чи іншого територіального об'єднання.

Законодавче закріплення основних засад і принципів місцевого самоврядування, на основі яких громадяни - жителі того чи іншого населеного пункту - можуть використовувати своє конституційне право на участь у місцевому самоврядуванні, потребує вдосконалення. Зокрема, питання проведення громадських слухань регламентується статтею 13 Закону України «Про місцеве самоврядування в Україні», яка визначає, що громадські слухання - це право зустрічатися з депутатами відповідної ради та посадовими особами місцевого самоврядування, під час яких члени територіальної громади можуть заслуховувати їх, порушувати питання та вносити пропозиції щодо питань місцевого значення, що належать до сфери місцевого самоврядування [2]. Таким чином, територіальна громада визначається як єдиний ініціатор проведення громадських слухань, що є недостатнім на сучасному етапі розвитку суспільно-політичних відносин.

Законодавство визначає територіальну громаду первинним суб'єктом місцевого самоврядування, основним носієм його функцій і повноважень. Саме на територіальну громаду покладені повноваження здійснення місцевого самоврядування, а відповідні ради можуть створювати за ініціативою жителів інші органи самоорганізації населення. Органи самоорганізації населення є однією із форм участі членів територіальної громади у вирішенні місцевих питань.

Територіальна громада як «первинний суб'єкт місцевого самоврядування створює представницькі органи - відповідні місцеві ради, які діють від іiі імені» [10, с. 123]. Місцеві ж ради «за ініціативою жителів можуть надавати дозвіл на створення інших форм самоорганізації населення» [11, с. 48]. Закон України «Про місцеве самоврядування в Україні» визначає, що орган самоорганізації населення є однією із форм участі членів територіальних громад сіл, селищ, міст тощо у вирішенні окремих питань місцевого значення [2]. Положення закону передбачає, що ці органи можуть наділятися частиною повноважень місцевих рад, а також мати власні повноваження. Проаналізувавши зміст вищезазначеного закону, варто зауважити, що органи самоорганізації населення можуть виконувати функції представницьких органів на зразок ради, але у меншому масштабі.

Висновки. Питання адміністративно-правового забезпечення проведення процедур громадського моніторингу та громадських слухань на місцевому рівні на етапі становлення громадянського суспільства в Україні є досить актуальним. Чинне законодавство визначає порядок проведення таких видів громадського контролю 3 метою забезпечення органами місцевої влади вирішення питань місцевого значення. Проте, на законодавчому рівні не прийнято типового положення, яке б регламентувало порядок ведення окремих видів громадського контролю.

Прийняття Державної програми громадського контролю щодо прийняття та ефективності застосування нормативно-правових актів органами місцевої виконавчої влади та місцевого самоврядування сприяло б: 1) спрощенню процедур здійснення громадського моніторингу та ініціювання проведення слухань; 2) визначенню переліку суб' єктів місцевого самоврядування, які самі можуть ініціювати проведення громадського моніторингу та обговорення важливих для функціонування громади питань шляхом громадських слухань; 3) окресленню кола суб'єктів, які мають право звернутися до відповідних органів, обов'язком яких є розгляд заяв про здійснення моніторингу та організація проведення слухань тощо.

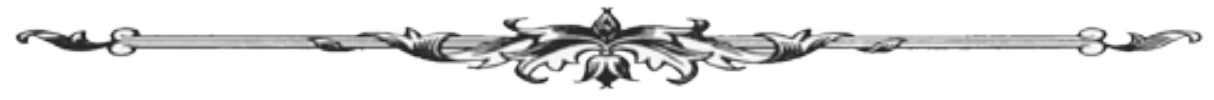




\section{Список використаних джерел:}

1. Конституція України: Закон України від 28.06.1996 № 254к/96-ВР.

2. Про місцеве самоврядування в Україні: Закон України від 21 травня 1997 № 280/97-ВР (станом на 1 квітня 2019 р.) / Верховна Рада України. Відомості Верховної Ради Украӥни. 1997, № 24, с.170.

3. Коментар до Конституції України / Авер'янов В.Б., Бойко В.Ф., Борденюк В.І. та інші. 2-ге вид., випр.. й допов. Київ : Ін-т законодавства Верховної Ради України, 1998. 568 с.

4. Нижник Н.Р. Природа та зміст адміністративної реформи в Україні / Реформування державного управління в Україні: проблема та перспективи; за заг. ред. В.В. Цвєткова. Київ : Просвіта, 2009. 214 с.

5. Тихомиров Ю. Организация и проведение правового мониторинга. Право и экономика. 2006. № 10. С.11-13.

6. Батанов О.В. Територіальна громада - основа місцевого самоврядування в Україні : монографія. Київ : Ін-т законодавства Верховної Ради України, 1998. 168 с.

7. Мушенок В.В. Improvement of legal regulation revenues local budgets. Зовнішня торгівля: економіка, фінанси, право. 2017. № 3. С. 90-98.

8. Мушенок В.В. Акти Кабінету Міністрів України у системі фінансового регулювання заходів у сільському господарстві. Міжнародний науковий журнал «Інтернаука». Серія «Юридичні науки» № 4. 2017. С. 36-39.

9. Бабаєв В. Управління міським господарством: теоретичні та прикладні аспекти : монографія. Харків : Магістр, 2004. 453 с.

10. Любченко П.М. Муніципальне право України. Навч. посіб. Харків : Видавництво «ФIHH», 2012. $496 \mathrm{c}$.

11. Адміністративне право України. Повний курс: підручник / Галунько В., Діхтієвський П., Кузьменко О., Стеценко С. та інші. Херсон : ОЛДІ-ПЛЮС, 2018. 446 с.

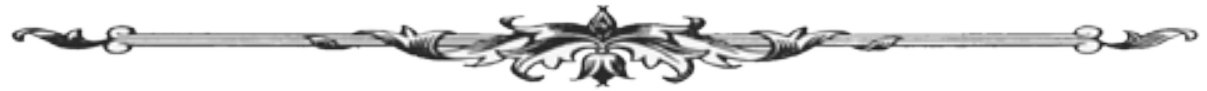

